\title{
Effect of vitamin e and selenium supplementation on the antioxidant content of milk and dairy products in dairy cows
}

\author{
Berta Vanda Sütő ${ }^{1}$ - Zsuzsanna Kárnyácki ${ }^{1}$ - Béla Béri ${ }^{2}$ \\ ${ }^{1}$ Körös-Maros Biofarm Ltd., 5711 Gyula, Külterület 2. \\ ${ }^{2}$ University of Debrecen Centre for Agricultural and Applied Economic Sciences, 4032 Debrecen Böszörményi street 138. \\ sberta@vipmail.hu
}

Keywords: dairy cow, milk, vitamin E, selenium, feed additives, antioxidant, functional dairy product

SUMMARY

In 2007, the aim of the Anyos Jedlik program and the call for tenders was to support application-oriented, strategic research and development projects, which can increase the competitiveness of the Hungarian economy. In the framework of our project, we intended to examine whether non-protected antioxidants - in this case: vitamin E and selenium - used as feed-additives can increase the antioxidant content of milk. The milk with an increased level of vitamin E and selenium content can be used for producing functional foods which will represent competitive products on the current market of milk products. Our results show that the use of vitamin E and selenium as feedadditives can significantly increase the amount of vitamin E and selenium in the milk and also in the diary products.

\section{LITERATURE}

Damage of the redox homeostasis in animals and the human body - as the latest research justify - could be the starting point of many diseases. The importance of antioxidant compounds comes from the fact that during the operation of the immune system, there are many highly reactive compounds generated, e.g. nitrogen and oxygen-free radicals. The organism as a whole - including the immune system itself - should be protected from the harmful effects of free radicals and this requirement is partly responsible for the need for antioxidant vitamins (Katner, 1998). We can see in the Hungarian population through mortality statistics that poor diet and lifestyle are responsible for morbidity and mortality. Nowadays, increasingly more people are being diagnosed with civilization-determined diseases: cardiovascular disease, osteoporosis, and unfortunately, cancer develop regardless of age (Jónás, 2001). To prevent and cure such diseases, functional foods could be used. The goal in the development of functional foods is to significantly enrich food with beneficial compounds which are proven to be beneficial for the body (Prokisch, 2008). To develop functional food, milk is suitable as a basic material, which is a valuable food itself. For this reason, we performed our antioxidant feeding experiments on dairy cattle. We used vitamin $\mathrm{E}$ and selenium among of the antioxidants. Experiments showed that antioxidant supplementation has also a significant effect in meat quality. Research results show that for 3 weeks before slaughter, feeding of $275 \mathrm{IU}$ vitamin E increased the vitamin E content of turkey tissues from $1.6 \mathrm{mg} / \mathrm{kg}$ to 5 $\mathrm{mg} / \mathrm{kg}$ (Sheldon, 1984). The addition of organic selenium increased selenium content in eggs and poultry meat significantly (Honey, 2004). In Japanese quail feeding experiments, it was also found that feeding inorganic selenium significantly increased the selenium content of eggs (Poland et al, 2004). Studies on the uptake of selenium in poultry found, that from sodium selenite the utilization of selenium was better than that of selenomethionine (Lawson et al, 1986; Sarudi et al, 2004). Sarudi et al (2004) also performed poultry feeding experiments with sodium selenite and organic selenium, and there were no significant differences between the selenium contents of the eggs. In addition, selenium and vitamin E are synergistic. It has been showed that selenium intake helps to decrease the absence of vitamin E (Gavrilovic and Matesic, 1984). Others examined the effectiveness of selenium therapy against "white muscle disease" in lambs, calves and foals, and the prevention of hepatitis in pigs. (Pais, 1980). A daily requirement of vitamin E for an adult person - according to the WHO is $12 \mathrm{mg}$, and $0.12 \mathrm{mg}$ from selenium. This quantity can be supplied into the body with adequate nutrition.

\section{OBJECTIVE}

In our experiment, we were looking for the answer as to with which non-protected antioxidants - in our case with vitamin E and selenium - could we increase the antioxidant contents of milk and dairy products. We investigated the following aspects.

Studies on milk:

- the effect of different doses of vitamin E on the antioxidant content of milk

- the effect of organic and inorganic selenium on the antioxidant content of milk

- the effect of Vitamin E and organic or inorganic selenium on the antioxidant content of milk

Studies on dairy products:

- the antioxidant content of dairy products, which were made from high antioxidant content milk 


\section{MATERIALS AND METHODS}

We did our feeding experiments between 15-29 September 2010. at the Körös-Maros Biofarm Ltd. We used Holstein-Friesian dairy cattles. The vitamin E and organic selenium (Sel-Plex 2300) from the Agrofeed Ltd., the organic selenium (Se 1\%) from Alltech Hungary Ltd were obtained. We applied individual feeding, once a day for 14 days. We constructed 7 groups. Every group contained 5 animals. The groups were homogeneous about stages of lactation and production records.

Groups:

-1. group, vitamin E supplement, $800 \mathrm{mg} /$ individual/day

-2. group, vitamin E supplement, $1900 \mathrm{mg} /$ individual/day

-3. group, vitamin E supplement, $3800 \mathrm{mg} /$ individual/day

-4. group, organic Se supplement, $10 \mathrm{mg} /$ individual/day

-5. group, organic Se $10 \mathrm{mg} /$ individual/day and $1900 \mathrm{mg}$ vitamin E/individual/day supplement

-6. group, inorganic Se supplement, $10 \mathrm{mg} /$ individual/day

-7. group, inorganic Se $10 \mathrm{mg} /$ individual/day and $1900 \mathrm{mg}$ vitamin E/individual/day supplement

During cheese processing we used 10 liters milk for $1 \mathrm{~kg}$ of $30 \%$ fat cheese and 3 liters milk for $1 \mathrm{~kg}$ of $3 \%$ fat yoghurt. Milk and milk products (cheese, yoghurt) were frozen until the laboratory tests. The Food-Analitika Szolgáltató és Innovációs Ltd. made the laboratory analysis. For the statistical analysis we used SPSS 13.0 and the testing of results paired $t$ test was applied.

\section{RESULTS AND DISCUSSION}

\section{Results of the milk analysis}

\section{Vitamin E, organic and inorganic selenium feeding experiment results}

The first three lines of the Table 1 contain the three different doses of vitamin E supplement group results. In groups 1 and 3, we can statistically prove, that the amount of vitamin $E$ changed significantly in milk $(\mathrm{p}=0.005$ and $p=0.022)$. In group 2 , significant increase in the volume of the vitamin was not detected $(p=0.062)$. The last two rows of the table you can see the results of those two groups, which were given pure (organic and inorganic) selenium supplement. The amount of selenium in the milk increased significantly $(p=0.008$ and $p=$ 0.007 ) in both groups. We can calculate from the data, that while the organic selenium increased $100 \%$, the inorganic selenium increased $255 \%$. Thus inorganic selenium increases the selenium content of milk more effectively than organic selenium.

The change of vitamin $E$ and selenium content in milk $(\mu \mathrm{g} / \mathrm{kg})$

\begin{tabular}{|l|c|c|c|}
\hline \multicolumn{1}{|c|}{ Groups (supplementation mg/nap) } & Before treatment & After treatment & Increase \\
\hline 1. group (vitamin E $800 \mathrm{mg} /$ day) & $588 \mathrm{a}$ & $1125 \mathrm{~b}$ & 447 \\
\hline 2. group (vitamin E $1900 \mathrm{mg} /$ day) & $698 \mathrm{a}$ & $1142 \mathrm{a}$ & 1011 \\
\hline 3. group (vitamin E $3800 \mathrm{mg} /$ day) & $533 \mathrm{a}$ & $1544 \mathrm{~b}$ & 46 \\
\hline 4. group (organic Se10 mg/day) & $46 \mathrm{a}$ & $92 \mathrm{~b}$ & 56 \\
\hline 6. group (inorganic Se10 mg/day) & $22 \mathrm{a}$ & $78 \mathrm{~b}$ & \multirow{2}{*}{} \\
\hline
\end{tabular}

\section{The combined vitamin $E$ and selenium feeding experiment results}

Table 2 contains the results of those two groups which groups received selenium and vitamin $\mathrm{E}$ supplementation at the same time. Group 5 got organic selenium and group 7 received inorganic selenium. We found significant differences in both groups in vitamin $\mathrm{E}$ and selenium levels. The results show that these groups, which got half the amount of vitamin E compared to group 3 (see Table 1), produced the same amount of vitamin in the presence of inorganic selenium. 
The co-change of vitamin $E$ and selenium content of milk

\begin{tabular}{|c|c|c|c|c|c|c|}
\hline \multirow{2}{*}{$\begin{array}{c}\text { Groups (1 } 900 \text { mg } \\
\text { vitamin E + } 10 \text { mg Se } \\
\text { supplement / day) }\end{array}$} & \multicolumn{3}{|c|}{ Vitamin $E(\mu \mathrm{g} / \mathbf{k g})$} & \multicolumn{3}{|c|}{ Selenium $(\mu \mathrm{g} / \mathrm{kg})$} \\
\hline & Before treatment & After treatment & Increase & Before treatment & After treatment & Increase \\
\hline 5. group (organic Se) & $751 \mathrm{a}$ & $1221 \mathrm{~b}$ & 470 & $40 \mathrm{c}$ & $138 \mathrm{~d}$ & 98 \\
\hline 7. group (inorganic $\mathrm{Se}$ ) & $693 \mathrm{a}$ & $1485 \mathrm{~b}$ & 739 & $38 \mathrm{c}$ & $136 \mathrm{~d}$ & 98 \\
\hline
\end{tabular}

\section{Results of the dairy products analysis}

\section{Vitamin $E$ and selenium test results}

The results in Table 3 show that the vitamin E contents of the control milk and cheese were similar to those for the experimental milk and cheese. The amount of vitamin $\mathrm{E}$ in the experimental yoghurt is just half that compared to the control product. We did not find any significant difference in the antioxidant level between the control and with the organic and inorganic selenium enriched milk. In contrast, we could detect significant differences between the products. The selenium residue of the control cheese was $67 \%$ and $23 \%$ of the yoghurt. The cheese, which was made from the organic selenium enriched milk contained $87 \%$ selenium residue, and the yoghurt contained $49 \%$. The cheese, which was made from the inorganic selenium enriched milk, had selenium residues in $100 \%$ and $53 \%$ of the yoghurt. It can be concluded that the most significant change was achieved by using the inorganic selenium.

The change of vitamin $E$ and selenium content of dairy products $(\mu \mathrm{g} / \mathrm{kg}$ )

\begin{tabular}{|c|c|c|c|c|c|}
\hline \multirow{2}{*}{ Product } & \multicolumn{2}{|c|}{ E-vitamin content } & \multicolumn{3}{c|}{ Selenium content } \\
\cline { 2 - 6 } & Control & $\begin{array}{c}\text { After vitamin E } \\
\text { treatment }\end{array}$ & Control & $\begin{array}{c}\text { After organic Se } \\
\text { treatment }\end{array}$ & $\begin{array}{c}\text { After inorganic Se } \\
\text { treatment }\end{array}$ \\
\hline Milk & 760 & 1640 & 260 & 330 & 320 \\
\hline Cheese & 3950 & 8900 & 1750 & 2880 & 3200 \\
\hline Yoghurt & 390 & 450 & 180 & 490 & 510 \\
\hline
\end{tabular}

\section{The combined vitamin $E$ and selenium results}

Table 4 shows us the results of those products which were made from the increased vitamin $\mathrm{E}$ and selenium content milk. As we see, there is dynamic increase in the antioxidant content, just as is shown in Table 3. It can be stated that we got the best results when vitamin $\mathrm{E}$ and the inorganic selenium were used together.

The co-change of vitamin $E$ and selenium content of dairy products $(\mu \mathrm{g} / \mathrm{kg})$

\begin{tabular}{|c|c|c|c|c|c|}
\hline \multirow{2}{*}{ Product } & \multicolumn{3}{|c|}{ Vitamin E content } & \multicolumn{3}{c|}{ Selenium content } \\
\cline { 2 - 6 } & Control & $\begin{array}{c}\text { Before } \\
\text { treatment with } \\
\text { vitamin E + } \\
\text { organic Se }\end{array}$ & $\begin{array}{c}\text { After } \\
\text { treatment with } \\
\text { vitamin E + } \\
\text { organic Se }\end{array}$ & $\begin{array}{c}\text { Control } \\
\text { Before } \\
\text { treatment with } \\
\text { vitamin E+ } \\
\text { organic Se } \\
\text { After treatment } \\
\text { with vitamin E } \\
+ \text { organic Se }\end{array}$ \\
\hline Milk & 760 & 1390 & 1170 & 260 & 290 \\
\hline Cheese & 3950 & 7120 & 6450 & 1750 & 3470 \\
\hline Yoghurt & 390 & 1040 & 1170 & 180 & 3640 \\
\hline
\end{tabular}

\section{CONCLUSIONS}

Our experiments were designed to show how feed supplementation - in our cease vitamin E and selenium in dairy cows can increase the antioxidant content of milk. Our results show that use of vitamin $\mathrm{E}$ and selenium as feed-additives can significantly increase the amount of vitamin E and selenium in milk, and in the diary 
products. We gave three different doses of vitamin E for three groups. Two groups had significant increases in the amount of vitamin. Both organic and inorganic selenium has increased significantly the selenium content of milk. The inorganic selenium increased more the selenium content of milk than did organic selenium. It was also found that we could achieve the best results when vitamin $\mathrm{E}$ and inorganic selenium are combined. We made dairy products from the milk, which was enriched with vitamin E. We could not find any differences about the antioxidant content between the control and the experimental products. However, using vitamin E with organic or inorganic selenium, we achieved massive change in the antioxidant levels. In case of selenium in the products, selenium requires further research. Based on these results, we can say that we are able to develop dairy products, which can expand the range of functional products. With consumption of $20 \mathrm{~g}$ of "Vitamin E Cheese", we can cover $12 \%$ of our daily vitamin E needs.

\section{REFERENCE}

Gavrilovic B.-Matesic D.-Kornet V. (1984): Selenium in the Retina and Chorioid of Some Animal Species. Third International Symposium. Part B 849-853

Jónás E. (2001): The role of functional foods in disease prevention, health-impact protection, Komplementer Medicina Electronic periodicals publication ISSN 1417-6548

Katner, M. (1998): Free radicals, exercise and antioxidant supplementation. Proceedings of the Nutrition Society 12.9 - 13.

Laws J. E.-Latshaw J.D-Biggert M. (1986): Selenium bioavailability in foods and feeds. Nutrition Reports International 33. 13-24.

Lengyel L.-Szabó M.-Bárdos L -Kiss Zs. (2004): Increased egg production and antioxidant-containing material utilized in mice, „Selenium in the inanimate and living nature”, Kerekasztal Konferencia, Gödöllő.

Mézes M. (2004): Selenium-enriched functional food production options, „Selenium in the inanimate and living nature”, Round Table Conference, Gödöllö.

Pais I. (1980): The role of micronutrients in agriculture. Agricultural Publishing, Budapest.

Prokisch J. (2008): Development of functional foods in the Food Science Department, University of Debrecen (Nagy J.- Schmidt J.-Jávor A. (2008): The future of food and health 91-107.)

Sarudi, I.-Csapónné K.Zs.-Szabó A.-Sütő Z.(2004): Selenium-enriched eggs. "Selenium in the inanimate and living nature”, Round Table Conference, Gödöllő.

Sheldon B.W.-Curtis P.A.-Dawson P.L.-Ferket P.R. (1984): Effect of dietary vitamin E on the oxidative stability, flavor, color, and volatile profiles of refrigerated and frozen turkey breast meat. Departments of North Carolina State University, Raleigh, North Carolina 276957624 